\title{
A long-term perspective on the Chrysochromulina bloom on the Norwegian Skagerrak coast 1988: a catastrophe or an innocent incident?
}

\author{
Jakob Gjøsæter ${ }^{1}$, Kyrre Lekve ${ }^{2}$, Nils Chr. Stenseth ${ }^{1,2, *}$, Hans Petter Leinaas ${ }^{2}$, \\ Hartvig Christie ${ }^{3}$, Einar Dahl ${ }^{1}$, Didrik S. Danielssen ${ }^{1}$, Bente Edvardsen ${ }^{4}$, \\ Frode Olsgard ${ }^{5}$, Eivind Oug ${ }^{6}$, Eystein Paasche ${ }^{4}$ \\ ${ }^{1}$ Institute of Marine Research, Flødevigen Marine Research Station, 4817 His, Norway \\ ${ }^{2}$ Division of Zoology, Department of Biology, University of Oslo, PO Box 1050 Blindern, 0316 Oslo, Norway \\ ${ }^{3}$ Norwegian Institute for Nature Research, PO Box 736 Sentrum, 0105 Oslo, Norway \\ ${ }^{4}$ Section for Marine Botany, Department of Biology, University of Oslo, PO Box 1069 Blindern, 0316 Oslo, Norway \\ ${ }^{5}$ Division of Marine Chemistry and Marine Zoology, Department of Biology, University of Oslo, PO Box 1050 Blindern, \\ 0316 Oslo, Norway \\ ${ }^{6}$ Norwegian Institute for Water Research (NIVA), Regional Office Grimstad, Televeien 1, 4890 Grimstad, Norway
}

\begin{abstract}
The long-term effects of the 1988 algal bloom (Chrysochromulina polylepis Manton et Parke) along the Norwegian Skagerrak coast are evaluated and discussed on the basis of several monitoring programmes. Effects on individual growth and survival of coastal cod and its population dynamics are analysed. Cod suffered a high mortality from June until November, and the 1988 yearclass was strongly reduced. Growth was only slightly affected. Furthermore, the effects at the community level are evaluated for the coastal fish community and the benthic communities. These communities were strongly affected on a short time scale, but recovered surprisingly fast. Populations of most organisms had recovered within months, and after $1 \mathrm{yr}$ few traces of the toxic bloom could be observed; after 4 to $5 \mathrm{yr}$ all communities had essentially recovered. As part of the review we also discuss to what extent harmful blooms are likely to reoccur, and conclude that blooms have reoccurred and will continue to do so. However, nothing can be concluded about the toxicity of such blooms. We expect that even large perturbations are unlikely to leave any profound long-lasting effects. The effects of the 1988 bloom are discussed within a theoretical framework including stability, resilience and inertia. In conclusion we emphasise the importance of long-term monitoring data; without such data the analyses reported in this paper would have been impossible.
\end{abstract}

KEY WORDS: Coastal communities $\cdot$ Monitoring $\cdot$ Toxic effects $\cdot$ Stochasticity $\cdot$ Resilience Resale or republication not permitted without written consent of the publisher

\section{INTRODUCTION}

The bloom of the flagellate Chrysochromulina polylepis Manton et Parke in May-June 1988 harmed or killed a large number of marine species in the upper

${ }^{*}$ Corresponding author. E-mail: n.c.stenseth@bio.uio.no
$20 \mathrm{~m}$ of the sublittoral along most of the Norwegian Skagerrak coast (Edvardsen et al. 1988, Underdal et al. 1989, Johannessen \& Gjøsæter 1990, Granéli et al. 1993). Dead fish could be seen lying on the bottom, and a photograph of a dying goldsinny wrasse was spread all over the world through the front-cover of Newsweek Magazine (August 1988, No. 31). Juvenile cod, settling in shallow waters in May-June, were 
almost exterminated. In Norway 800 tonnes of farmed fish were killed, and in Sweden, 100 tonnes, the total economic loss amounting to approximately 10 million $€$ (approx. 9 million US \$) (Skjoldal \& Dundas 1991). Expressions such as 'catastrophe' and 'disaster' were commonly used in newspapers, on television, and the radio. Scientists supplied the media with rather worrying descriptions of what seemed to be happening. Now, more than a decade later, we may provide a balanced assessment of the effects of the bloom.

In this assessment, besides reporting some new data and analyses, we summarise available information on the short-term and long-term effects of the Chrysochromulina bloom. In particular, we describe the mortality of cod during 1988 as deduced from a tagging experiment conducted in one of the Norwegian Skagerrak fjords (Danielssen \& Gjøsæeter 1994, Julliard et al. 2000). We also report on analyses of entire biotic communities before, during and after the bloom: first we consider the entire fish community (as monitored by beach seine hauls) as well as the demersal communities; then, we summarise available information on bottom communities (both hard- and soft-bottom fauna). On the basis of the empirical findings, we provide a more general discussion on the resilience and stability (see e.g. Holling 1973, Underwood 1989) of the ecosystem along the Norwegian Skagerrak coast, which appropriately may be considered a non-equilibrium system (see e.g. Murdoch 1994).

\section{BIOLOGY OF THE ALGA, AND DEVELOPMENT OF THE BLOOM AND ITS TOXICITY}

\section{Taxonomy and general biology}

The genus Chrysochromulina, with about 50 named species, belongs to the class Prymnesiophyceae and the division Haptophyta (Jordan \& Green 1994). In addition to flagella, these algae possess a haptonema which may be involved in the capture and handling of particles (Kawachi \& Inouye 1995). All known Chrysochromulina species are photosynthetic, although observations of particle uptake in some species suggest a potential for mixotrophy (Edvardsen \& Paasche 1998). During the harmful stage of the C. polylepis bloom in 1988 primary productivity was high (Dahl et al. 1989), indicating autotrophic growth. The C. polylepis cell size $(10 \times 7 \mu \mathrm{m})$ categorizes it as small nanoplankton algae. Two motile cell types of this species have been described, which seem to represent stages in a haploid-diploid life cycle (Edvardsen \& Vaulot 1996). Chrysochromulina polylepis is eurythermal and euryhaline with a maximum growth rate of about 1.3 divisions $d^{-1}$ (Edvardsen \& Paasche 1998).

\section{Origin and progress of the bloom}

The bloom was first noted on 5 May 1988 in terms of anomalous behaviour among farmed fish along the western coast of Sweden. It reached the Norwegian coast in the inner Skagerrak on 9 May (Dahl et al. 1989, Fig. 1A). The dominating alga was soon identified as the prymnesiophyte flagellate Chrysochromulina polylepis Manton et Parke (Dahl et al. 1989). The bloom was transported with the Baltic Current and then the Norwegian Coastal Current (NCC) along the Norwegian coast (see e.g. Danielssen et al. 1996, 1997), following the normal trajectory of this current system. By the middle of May it reached Lindesnes (the southernmost tip of Norway). During May 17 to 24 the bloom was carried offshore in the western and central Skagerrak by westerly winds. On May 22 the wind again turned easterly and brought the bloom further along the Norwegian coast. By the end of May its propagation ended along the western coast of Norway. During the bloom period (May-June) the bloom covered an area of approximately $75000 \mathrm{~km}^{2}$ including most of the Skagerrak and the entire Kattegat (Lindahl \& Dahl 1990). Maximum concentrations of C. polylepis were 50 to $100 \times 10^{6}$ cells $\mathrm{l}^{-1}$, usually concentrated in a thin layer near the pycnocline.

The Chrysochromulina polylepis bloom occurred during a period with weak winds of changing directions in the Skagerrak, the second lowest wind level for the preceding $28 \mathrm{yr}$, and irradiance well above the mean for the 1980s (Barth \& Nielsen 1989). Heavy rain and large freshwater run-off during the preceding mild winter caused an abnormally strong outflow from the Baltic Sea. A well-defined surface layer with above-normal temperatures of 8 to $10^{\circ} \mathrm{C}$ and an exceptionally low salinity of about 28 psu eventually extended over the entire Kattegat as well as the Norwegian sector of the Skagerrak. Nitrate concentrations in this brackish water mass were low; however, as concentrations of phosphate and silicate were just at, or below, the detection limit, N:Si and N:P nutrient ratios were high (Dahl et al. 1989, Granéli et al. 1993). The high N:P ratio may suggest potential phosphorus limitation. The termination of the bloom on the west coast of Norway in June may have been due to nutrient deficiency (Brockmann \& Dahl 1990, Johnsen \& Lømsland 1990).

Elevated subsurface nitrate concentrations early in 1988, caused by water transport from the German Bight, were at one time thought to have triggered the bloom (Aksnes et al. 1989). This now seems unlikely since a large influx of nitrate in the winter and early spring has proved to be a recurrent phenomenon in the area (Aure et al. 1998) while toxic Chrysochromulina blooms are not (Edvardsen \& Paasche 1998). 
A
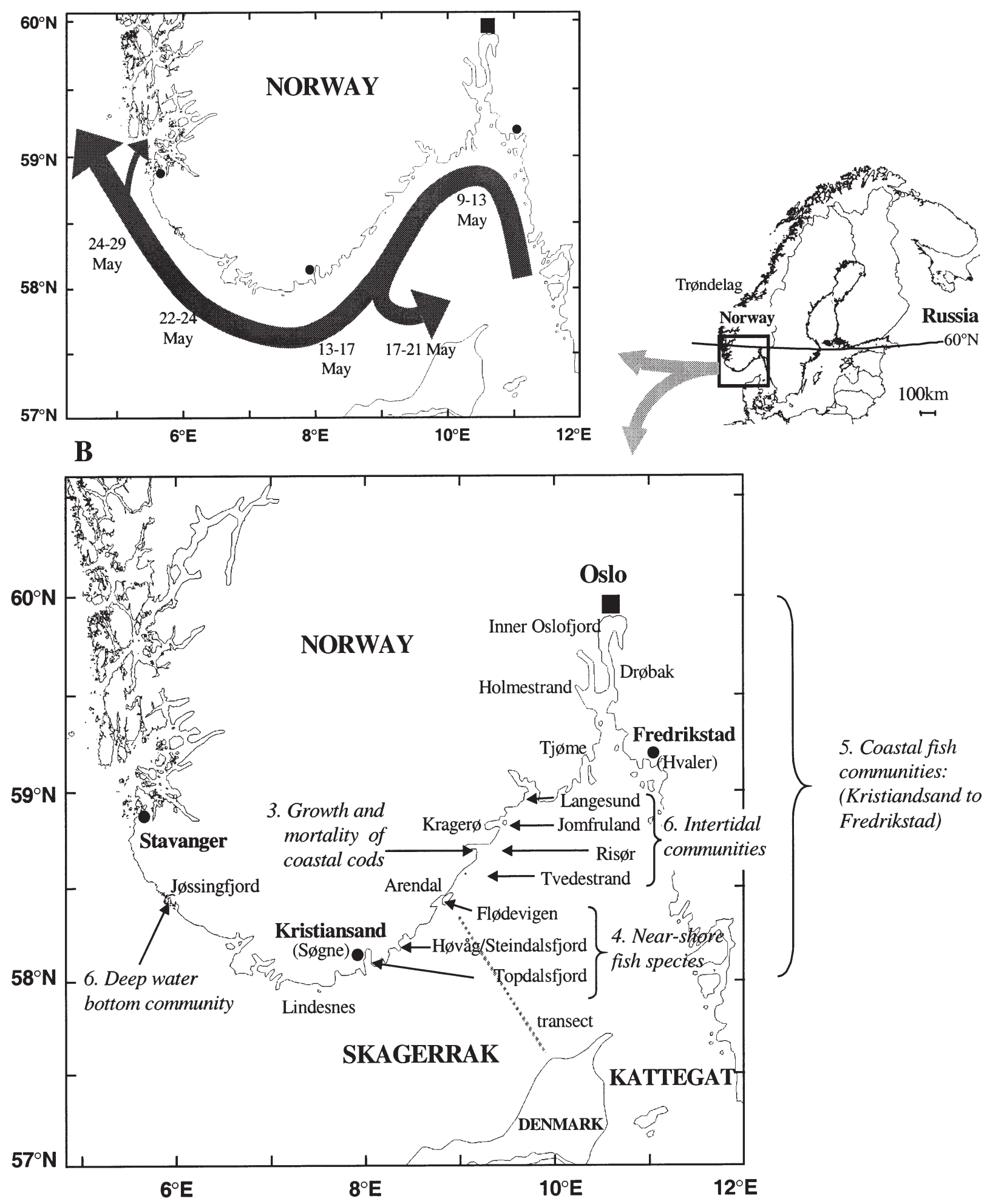

Fig. 1. Chrysochromulina polylepis. (A) The evolution of the bloom in the Skagerrak during spring 1988 (from Dahl et al. 1989). Inset in the figure show approximate dates of the development of the bloom. (B) The sampling areas of these investigations. The numbers on the map correspond to section numbers in the text. The grey dotted line shows the sampling transect from Arendal to Denmark (see Section 2) 


\section{Toxicity and immediate impact of the bloom}

A screening for toxins in water samples and mussels collected during the bloom revealed the presence of 1-acyl-3-digalactosylglycerol and octadecapentaenoic acid, 2 haemolytic compounds likely to increase fish mortality (Yasumoto et al. 1990). Any other toxins that might have been produced by Chrysochromulina polylepis during the bloom have not yet been characterised. In the closely related species Prymnesium parvum, however, the hemolytic toxins have been extensively studied (Igarashi et al. 1995).

In the early phase of the bloom in the Skagerrak, the algae were present in open water in the upper 0 to $10 \mathrm{~m}$. The bloom did not severely affect the more sheltered fjords with restricted water exchange. During the later stages of the bloom, the bulk of the cells were recorded as subsurface populations associated with the pycnocline at 10 to $30 \mathrm{~m}$ depth. The bloom in the Kattegat was continually in contact with the pycnocline (Skjoldal \& Dundas 1991).

Farmed and wild fish, molluscs, echinoderms, ascidians, cnidarians, sponges and red algae were heavily affected during the bloom (Skjoldal \& Dundas 1991). Death of animals was generally caused by damage to cell membranes and failure in keeping the ionic balance (Skjoldal \& Dundas 1991). For fish, this was manifested in gill damage and respiration failure. Chrysochromulina polylepis proved less harmful to fish at salinities of 20 psu or less (Leivestad \& Serigstad 1988, Skjoldal \& Dundas 1991), either because less toxin was produced or because fish were less sensitive to the toxin at low salinity.

\section{Monitoring algal blooms since 1988}

A regular algal monitoring programme, including the Flødevigen area (see Fig. 1B) as well as monthly transects across Skagerrak, began in 1988. In the course of this work it has been found that Chrysochromulina spp., including C. polylepis, are common in the Skagerrak; their main season being May-June (Dahl \& Johannessen 1998). Bloom duration and concentrations of Chrysochromulina spp. vary substantially from one year to another. In 1994 and 1995, high concentrations $\left(10\right.$ to $50 \times 10^{6}$ cells $\left.\mathrm{l}^{-1}\right)$, largely representing C. polylepis, were recorded. Samples collected in both years were found to be toxic in brine shrimp assays (Dahl et al. 1998); however, no toxic effects were observed in the field. The realised toxicity in C. polylepis is thus highly variable, and seems to be promoted by unknown environmental factors that were associated with the peculiar hydrographical and meteorological conditions such as those in early in 1988.
Other monitoring programmes, mainly involving fish, but also some including benthos, were conducted before as well as after the 1988 algal bloom. About 80 fixed stations have been sampled by beach seine according to a standardised protocol since 1919 (see Fig. 1B and Section 5). Further, a monitoring programme of deep-water soft-bottom fauna in Jøssingfjord has been carried out since the mid 1980s (see Fig. 1B and Section 6). We will refer to these monitoring programmes in the following sections of this review.

\section{EFFECTS ON INDIVIDUAL GROWTH AND MORTALITY OF COASTAL COD}

\section{Release-recapture experiments on cod}

Growth and demography of cod were studied using recaptures of tagged fish released in the Risør area (Fig. 1A) during 1986 to 1989 (Danielssen \& Gjøsæter 1994, Julliard et al. 2000). Two categories of fish were released: artificially reared, 6 mo old fish were released in October in 1986, 1987, 1988 and 1989; wildcaught, mostly about 18 mo old fish selected from commercial catches in the Risør area, were released in December 1986, 1988 and 1989. Altogether, 36728 reared and 2415 wild-caught fish were released, out of which a total of 4382 were recaptured (until 1993). The total percentage recaptured varies from 2.0 to 12.9 for the artificially reared cod and from 20.7 to 28.4 for the wild-caught cod. Of those recaptured 996 (23\%) were released again.

\section{Growth of cod during the 1988 algal bloom}

Using the release-recapture data on cod, the growth of tagged cod was studied. If the increased mortality during the algal bloom and the following months was caused by starvation, we would expect the fish growth to be affected. The length of all fish was measured when they were released as well as when recaptured (with a few exceptions). Data were divided into categories according to the number of days in the sea (Table 1). A significant difference in growth between fish having experienced the algal bloom and fish not having been exposed to the algal bloom was only observed for fish recaptured after 700 to $900 \mathrm{~d}$ in the sea. Pooling all recaptures, fish exposed to the bloom can be seen to grow slightly slower than those not being exposed (Table 1, bottom row). Hence, there is some evidence suggesting starvation among the younger age-classes.

Studying the length of wild-caught fish in the Risør area, Gjøsæter \& Danielssen (unpubl. data) collected 
Table 1. Number and $\mathrm{cm}$ change in mean length $\left(N_{\mathrm{n}}, \Delta L_{\mathrm{n}}\right)$ of fish that did not experience the algal bloom in 1988, and fish that were in sea during the algal bloom $\left(N_{\mathrm{a}}, \Delta L_{\mathrm{a}}\right)$. $F$ and probability (p) of analysis of variance, to test if the growth measurements could come from the same statistical populations, are also given. ${ }^{*}$ Values significant at the 0.05 level (Bonferroni adjusted p of 0.007 ; Sokal \& Rohlf 1995)

\begin{tabular}{|lrrrrrc|}
\hline \multirow{2}{*}{$\begin{array}{l}\text { Days } \\
\text { in sea }\end{array}$} & \multicolumn{2}{c}{$\begin{array}{l}\text { Not exposed } \\
\text { to algae }\end{array}$} & \multicolumn{2}{c|}{$\begin{array}{c}\text { Exposed } \\
\text { to algae }\end{array}$} & $F$ & $\mathrm{p}$ \\
& $N_{\mathrm{n}}$ & $\Delta L_{\mathrm{n}}$ & \multicolumn{1}{c}{$N_{\mathrm{a}}$} & $\Delta L_{\mathrm{a}}$ & & \\
\hline $30-100$ & 133 & 3.7 & 1 & & & \\
$100-200$ & 315 & 3.8 & 0 & & & \\
$200-300$ & 757 & 3.9 & 2 & 0.037 & & \\
$300-400$ & 600 & 3.9 & 19 & 0.040 & 0.137 & 0.711 \\
$400-500$ & 345 & 4.0 & 13 & 0.042 & 0.220 & 0.639 \\
$500-600$ & 483 & 4.0 & 13 & 0.042 & 0.164 & 0.686 \\
$600-700$ & 254 & 3.8 & 28 & 0.035 & 1.961 & 0.163 \\
$700-900$ & 321 & 3.6 & 65 & 0.032 & 9.396 & $0.0023^{*}$ \\
$>900$ & 132 & 3.1 & 51 & 0.028 & 3.627 & 0.0584 \\
All periods & 3348 & 3.8 & 192 & 0.034 & 21.369 & $<0.0001^{*}$ \\
\hline
\end{tabular}

about 2000 cod during the period 1986 to 1996 using trammel nets. Of these 1686 had been exposed to the algal bloom whereas 140 had not. Sufficient data were available only for fish in the 2 to $5+$ yr old age-classes (fish caught during 1988 were omitted from the analysis due to their high mortality; cf. Julliard et al. 2000). To test whether the 2 groups had the same length at given ages when recaptured, analyses were conducted as shown in Table 2. No clear-cut difference between the fish surviving 1988 and those that were not exposed to the 1988 bloom can be seen. Hence, there is no evidence that older fish starved. The lack of any difference might, however, be caused by a size-dependent selection during the bloom: small fish might have died at a higher rate, so that only the larger ones survived and were eventually recaptured by fishermen after the algal bloom.

Table 2. Number and cm change in mean length $\left(N_{n}, L_{n}\right)$ of fish that did not experience the algal bloom in 1988, and fish that were in the sea during the algal bloom $\left(N_{\mathrm{a}}, L_{\mathrm{a}}\right) . F$ and probability (p) of analysis of variance, to test if the growth measurements could come from the same statistical populations, are also given

\begin{tabular}{|c|c|c|c|c|c|c|}
\hline \multirow[t]{2}{*}{ Age } & \multicolumn{2}{|c|}{$\begin{array}{l}\text { Not exposed } \\
\text { to algae }\end{array}$} & \multicolumn{2}{|c|}{$\begin{array}{l}\text { Exposed } \\
\text { to algae }\end{array}$} & \multirow[t]{2}{*}{$F$} & \multirow[t]{2}{*}{$\mathrm{p}$} \\
\hline & $N_{\mathrm{n}}$ & $L_{\mathrm{n}}$ & $N_{\mathrm{a}}$ & $L_{\mathrm{a}}$ & & \\
\hline 2 & 715 & 41.30 & 65 & 41.23 & 0.012 & 0.911 \\
\hline 3 & 206 & 47.40 & 36 & 49.27 & 2.10 & 0.149 \\
\hline 4 & 62 & 54.79 & 25 & 48.32 & 15.15 & 0.0002 \\
\hline 5 & 24 & 59.71 & 6 & 55.67 & 0.794 & 0.380 \\
\hline Total & 1007 & & 132 & & & \\
\hline
\end{tabular}

\section{Survival of cod during the 1988 algal bloom}

Age- and time-dependent mortality rates of cod in the Risør area were analysed using the tagged artificially reared fish individuals (Julliard et al. 2000). Different models making different sets of assumptions about time- or age-dependent mortality rates were considered. Nested models were then compared using likelihood ratio tests (LRT; Burnham et al. 1987, Lebreton et al. 1992). Non-nested models were compared using the AIC-selection criterion (Akaike Information Criterion; see, e.g. Burnham \& Anderson 1998: a low AIC-value suggests a better model).

Analyses demonstrated strong effects of both age and year on survival (Julliard et al. 2000). A model constraining survival to be equal across age-classes except in 1988 was concluded to describe the data appropriately. The effect of the algal bloom was strong: the between-year variation of survival was entirely due to a difference in survival in 1988. Models in which the algal bloom started and ended in different months were considered. The model with the smallest AIC (i.e. the best model) assumed an effect starting in June 1988 and ending in November 1988. Hence, the effect of the bloom is concluded to last for approximately $5 \mathrm{mo}$ (Fig. 2). This suggests that survival was profoundly af-

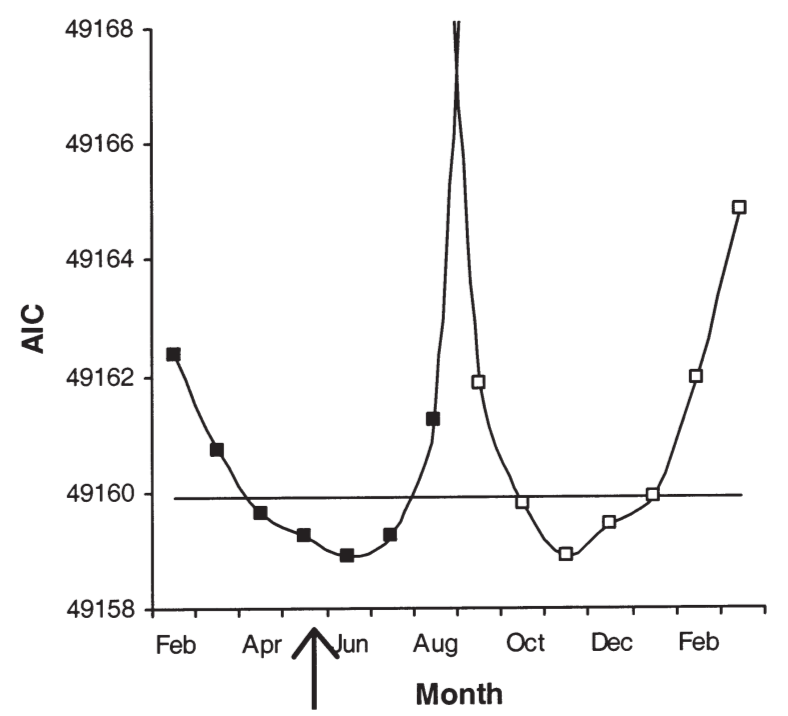

Fig. 2. Determining the span of the algal bloom effect on survival. A series of models with various dates of beginning and end of the algal bloom effect were fitted to the data. The best one according to AIC was for the beginning of the effect in June 1988 and the end of the effect in November 1988. Fixing one of the limits, presented here is the AIC of models where the other limit is moved by up to 3 mo ( $\square$ represents the beginning; $\square$ represents the end of the algal bloom). Horizontal line is for minimum $\mathrm{AIC}+1$, and indicates the $95 \%$ confidence interval of the estimated beginning and end. Arrow indicates the date of occurrence of the algal bloom; reproduced from Julliard et al. (2000) 
fected for several months after the end of the visible part of the Chrysochromulina polylepis bloom (for further details, see Julliard et al. 2000).

\section{Migration of cod during the 1988 algal bloom}

A possible explanation for the deduced low local survival during the bloom is that fish migrated to places with lower algal densities. If so, long-distance recapture rate is expected to be higher for fish that experienced the algal bloom than for fish that did not. Hence, we studied the distance-dependent recovery rates after the bloom of fish released prior to the bloom as compared to recapture rates of fish of the same age, released after the bloom (Fig. 3; note log-scale). Recovery rates above $14 \mathrm{~km}$ after $225 \mathrm{~d}$ in the sea were $0.30 \%$ for fish released in October 1987 as compared to $0.33 \%$ for fish released in October 1988 and 1989. Recovery rates above $20 \mathrm{~km}$ after $580 \mathrm{~d}$ in the sea were 0.17 and $0.20 \%$ for fish released in October 1987 and in October 1988/1989, respectively. In contrast, recovery rates within $6 \mathrm{~km}$ were strongly reduced for fish exposed to the algal bloom. Recovery rates within $6 \mathrm{~km}$ after $225 \mathrm{~d}$ in the sea were 2.13 and $9.22 \%$ for fish released in October 1987, and in October 1988/1989, respectively, while recapture rates within $6 \mathrm{~km}$ after $580 \mathrm{~d}$ in the sea were 1.59 and $2.79 \%$ for fish released in October 1987 and in October 1988/1989, respectively.

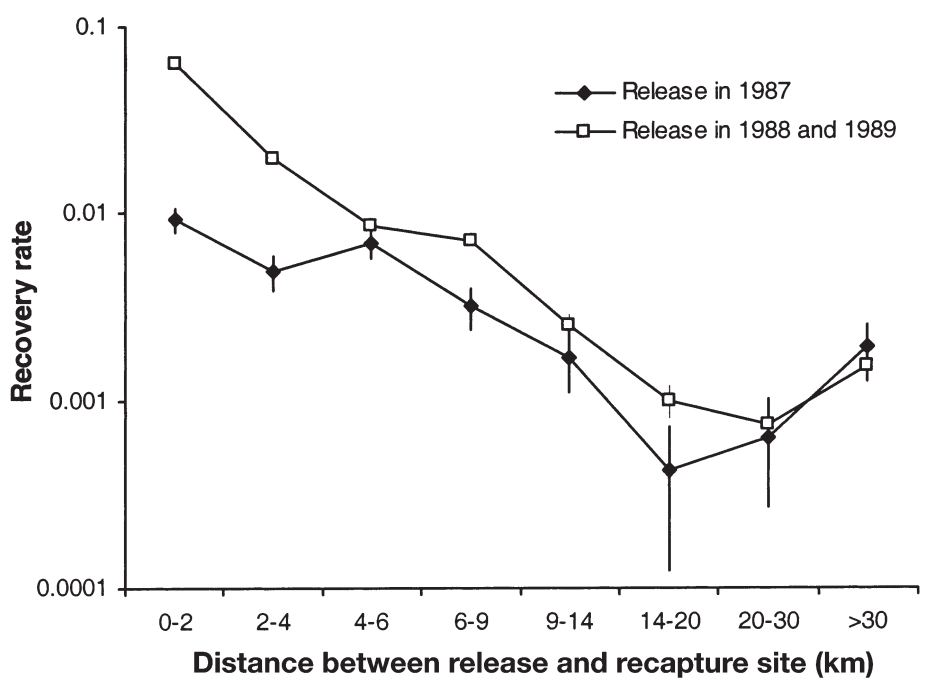

Fig. 3. Recapture rates (excluding recaptures by eel-traps) as a function of distance from the site of release for artificially reared fish released in 1987, and in 1988-1989 combined. As measurements at recapture were sometimes inaccurate, obviously wrong data had to be rejected. Fish growth equal to 0 or negative growth, and growth higher than $0.1 \mathrm{~mm} \mathrm{~d}^{-1}$ was rejected. Vertical bars represent \pm SE. Note the logarithm scale for recapture rate
Hence, the algal bloom seems to have reduced recovery rates only in the vicinity of the release area, while the recovery rate at longer distance appears unaffected. One explanation might be that dispersal rates were not affected by the algal bloom, but that fish that did disperse found themselves in areas less exposed to the toxic algae. However, the dispersion of the fish tagged in 1986 and 1987 (before the bloom) does not confirm such a view. All recovered fish migrating more than 2 nautical miles are shown in Fig. 4. Those recovered within the fjord system were evenly distributed and there were no indications that they had found any refuges. Those migrating out of the fjord were, with few exceptions, recovered in areas supposed to be equally affected by the bloom as the Risør area. Thus, an alternative explanation is that the older fish migrate into deeper water. As the bloom was confined to the water masses above the pycnocline, younger fish that were dependent on the shallow shore were more vulnerable to the toxic algae.

\section{EFFECTS ON POPULATIONS OF NEAR-SHORE FISH SPECIES}

Every year from 1919 to the present, a large number of sites between Kristiansand and the NorwegianSwedish border (Fig. 1B) have been monitored in September/October (i.e. after the time of the year the 1988 bloom took place) through beach seine hauls using a standardised protocol. For details about this monitoring programme, see Stenseth et al. (1999). During the last $25 \mathrm{yr}$, between 70 and 80 stations have been monitored continuously. Material from these surveys has been used to analyse spatio-temporal patterns of the fish species inhabiting the sublittoral zone; see Tveite (1971), Fromentin et al. (1997), Lekve et al. (1999) and Stenseth et al. (1999).

In order to evaluate whether fish species within the near-shore assemblages had changed their abundance during the algal bloom 3 sets of analyses were made:

The catches for 1988 were compared to those of 1985-87 and 1989-91.

The average catches for the period 1985-87 were compared to those of the period 1989-91.

The average catches for the period 1979-87 were compared to those of the the period 1989-97.

The abundant gadoid species and several other species in the coastal zone have a rather short generation time. A time span of investigation of $3 \mathrm{yr}$ before and after the bloom will probably be sufficient to capture changes taking place during the pre-recruitment period of these species. A time span of investigation of about $8 \mathrm{yr}$ will correspond to the life span of several of these species, thus capturing changes when recruit- 


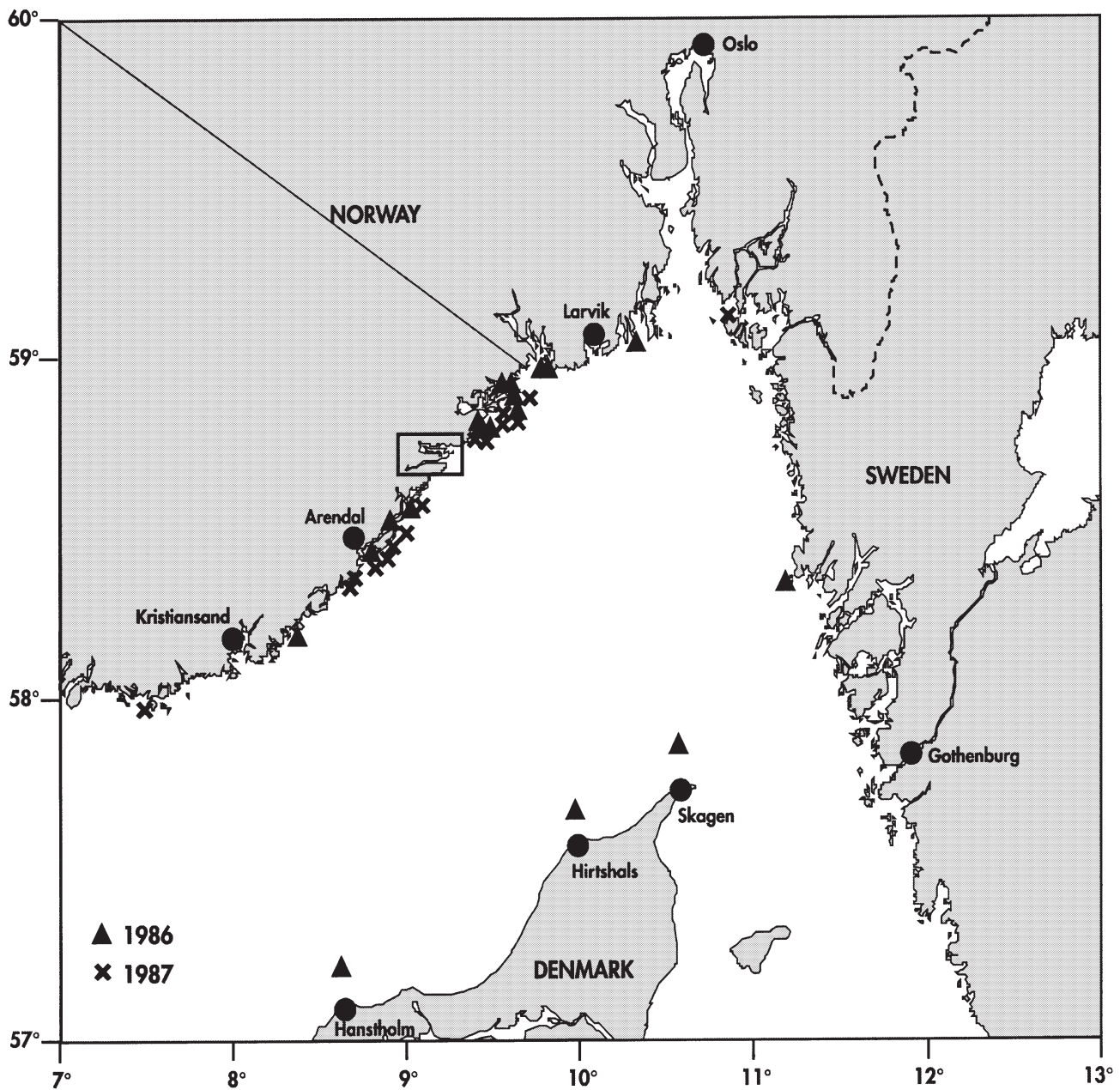

Fig. 4. Long-distance recaptures from a releaserecapture experiment in the Risør area (Danielssen \& Gjøsæter 1994, Julliard et al. 2000). The square contains the release area. ( $\mathbf{\Delta})$ Recaptures of fish released in 1986; (X) recaptures of fish released in 1987

ment is completed. Between (and including) Søgne and Kragerø 52 stations, visited for at least $15 \mathrm{yr}$, were studied to investigate these changes. Analyses of variance (ANOVAs) were used to compare species with numerical counts (adding a constant of 1 before taking natural logarithms to stabilise the variance; Sen \& Srivastava 1990), whereas a Mann-Whitney test was used to compare species with categorical counts (Table 3). For species for which we had abundance data mean, the number of fish per station was calculated, while an average appearance index was used for species for which only categorical data were available (0 signifying no individuals to 5 for the most abundant class; Table 3, Fig. 5).
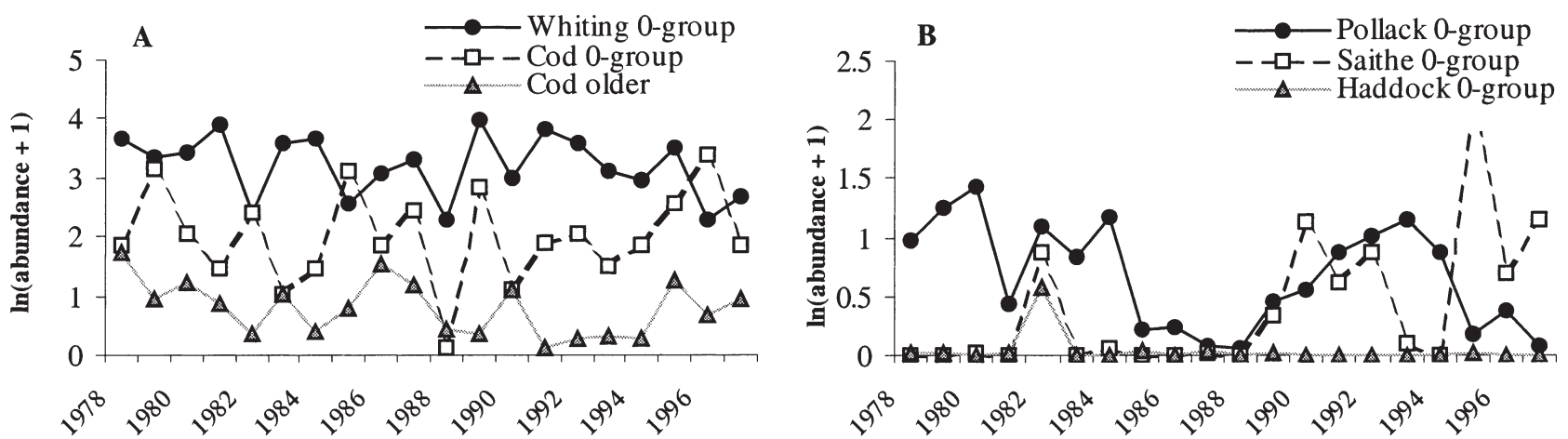

Fig. 5. Abundance (on logarithmic scale) of selected species from beach seine hauls 1978-97 
Table 3. Significance tests (ANOVA for species with numerical data, Mann-Whitney test for species with categorical counts) for difference between the periods before and after the algal bloom. (+) denotes significantly more fish after the bloom, and (-) significantly more fish before. Average number/index for a haul is also given for the whole period after the bloom. (Sequence of species/categories is given according to decreasing occurrence in the samples)

\begin{tabular}{|c|c|c|c|c|c|}
\hline Common name & Scientific name & $\begin{array}{c}1988 \text { vs } \\
1985-91\end{array}$ & $\begin{array}{c}1985-87 \text { vs } \\
1989-91\end{array}$ & $\begin{array}{c}1978-87 \text { vs } \\
1989-97\end{array}$ & $\begin{array}{r}\text { Mean no./ } \\
\text { index 1988- }\end{array}$ \\
\hline \multicolumn{6}{|c|}{ Fish species with numerical data } \\
\hline Whiting (0-group) & Merlangius merlagus & - & - & - & 32.6 \\
\hline Cod (0-group) & Gadus morhua & - & ns & ns & 10.4 \\
\hline Saithe (old) & Pollachius virens & ns & - & ns & 1.17 \\
\hline Saithe (0-group) & Pollachius virens & ns & + & + & 1.04 \\
\hline Ballan wrasse & Labrus bergylta & - & + & + & 0.96 \\
\hline Cod (old) & Gadus morhua & - & - & - & 0.87 \\
\hline Pollack (0-group) & Pollachius pollachius & - & + & - & 0.81 \\
\hline Pollack (old) & Pollachius pollachius & ns & - & ns & 0.51 \\
\hline Sea trout & Salmo trutta & ns & ns & + & 0.34 \\
\hline Grey gurnard & Eutrigla gurnardis & + & + & + & 0.22 \\
\hline Mackerel & Scomber scombrus & ns & ns & ns & 0.17 \\
\hline Eel & Anguilla anguilla & ns & ns & ns & 0.14 \\
\hline Plaice & Pleuronectes platessa & ns & ns & ns & 0.10 \\
\hline Butterfish & Pholis gunnellus & ns & ns & ns & 0.10 \\
\hline Cuckoo wrasse (female) & Labrus bimaculatus & - & - & - & 0.07 \\
\hline Dragonet & Callionymus lyra & ns & ns & ns & 0.04 \\
\hline Brill & Scophthalmus rhombus & ns & ns & ns & 0.04 \\
\hline Turbot & Psetta maximus & ns & ns & + & 0.02 \\
\hline Lemon sole & Microstomus kitt & ns & ns & ns & 0.01 \\
\hline Sole & Solea solea & ns & ns & ns & 0.01 \\
\hline Pogge & Agonus cataphractus & - & ns & ns & 0.01 \\
\hline Haddock & Melanogrammus aeglefinus & ns & ns & ns & 0.004 \\
\hline Topknot & Zeugopterus punctatus & ns & ns & ns & 0.002 \\
\hline Cuckoo wrasse (male) & Labrus bimaculatus & ns & - & - & 0.000 \\
\hline \multicolumn{6}{|c|}{ Fish species with categorical counts } \\
\hline Gobies (demersal) & Gobius niger/Pomatoschistus minutus & + & ns & + & 2.88 \\
\hline Goldsinny & Ctenolabrus rupestris & - & + & + & 2.56 \\
\hline Corkwing & Symphodus melops & - & + & + & 2.47 \\
\hline Rock cook & Centrolabrus exoletus & ns & + & + & 0.24 \\
\hline Spotted goby & Gobiusculus flavescens & ns & + & + & 2.08 \\
\hline Flounder & Platichthys flesus & + & ns & ns & 0.92 \\
\hline Stickleback & Gasterosteus aculeatus & ns & ns & - & 0.77 \\
\hline Pipe-fishes & Syngnathus spp. & ns & ns & - & 0.65 \\
\hline Fifteen-spined stickleback & Spinachia spinachia & - & ns & - & 0.63 \\
\hline Scad & Trachurus trachurus & ns & + & + & 0.47 \\
\hline Herring & Clupea harengus & ns & ns & - & 0.33 \\
\hline Sea scorpions & Myoxocephalus scorpius/Taurulus bubalis & is - & ns & ns & 0.29 \\
\hline Gobies (pelagic) & Chrystallogobius linearis/Aphia minuta & ns & + & + & 0.28 \\
\hline Sand eels & Ammodytidae & ns & ns & ns & 0.28 \\
\hline Sprat & Sprattus sprattus & ns & ns & ns & 0.25 \\
\hline Poor-cod & Trisopterus minutus & ns & ns & - & 0.11 \\
\hline Eel pout & Zoarces viviparus & ns & - & - & 0.08 \\
\hline Dab & Limanda limanda & ns & ns & ns & 0.07 \\
\hline Long rough dab & Hippoglossoides platessoides & ns & - & - & 0.01 \\
\hline
\end{tabular}

Of 42 species (or groups of species) studied, 11 decreased, 3 increased and 29 did not deviate significantly in 1988 compared to the years 1985-87 and 1989-91. Comparing 1985-87 to 1989-91, 8 species (or groups of species) decreased, 10 increased and 25 did not change significantly. Comparing the period 1989-97 to $1979-87,12$ species (or groups of species) decreased, 12 increased and 19 did not change significantly.
Among the 11 species caught in significantly lower quantities in 1988 than in the rest of the period 1985-91, both species spawning before the bloom (7) and after the bloom (4) were found. Five species had pelagic eggs and 6 benthic eggs. The 3 species being more abundant during 1988 as compared to the years before and after included both summer (2) and winter (1) spawners, and included species with benthic (2) and pelagic (1) eggs. 
The species that were less abundant during 1989-91 than during 1985-87 were (with the exception of the Labrus bimaculatus) winter or spring spawners either with a wide distribution or with an affinity to cold waters. Among those species more abundant during the post-bloom period, 8 species (or groups of species) were summer spawners, while 2 were spring spawners. Seven of these have affinity to warm waters, while none has affinity to cold waters.

Nine of the species (or groups of species) that were more abundant 3 yr after the bloom than before were also more abundant 9 yr after the bloom. Daily temperature measurements sampled at the Institute of Marine Research, Flødevigen (cf. Fig. 1) demonstrate that the temperature increased after 1988 compared to the preceding decade, especially in the winter. Hence, it seems reasonable to assume that the increased temperature after 1988 had more of an effect than the algal bloom.

Most of the more abundant species experienced a similar effect of the algal bloom - they decreased in the short run, and recovered within a few years (Table 3 ). Only the demersal gobies (black goby Gobius niger and sand goby Pomatoschistus minutus) displayed an increase in 1988 (Table 3). The small gobies are a major prey of several of the gadoids (cod type fish), and thus might have benefited from the low abundance of gadoids. Indeed the gobies showed an opposite abundance pattern to that of 0-group cod and 0-group whiting displayed an opposite pattern of abundance around the algal bloom year.

Altogether only negligible long-lasting effects, if any, could be detected in the populations of near-shore fish following the 1988 algal bloom.

\section{EFFECTS AT THE COMMUNITY LEVEL: THE COASTAL FISH SPECIES}

\section{Effects on species richness}

The data used for analysing shallow-water fish communities were derived from the beach seine sampling programme described in Section 4. Seventy stations from Kristiansand to Fredrikstad (Fig. 1B) were studied. Twenty-one fish species for which numerical data existed were included (see Lekve et al. 1999 for a list of species). Stations were grouped into 12 fjords/areas (see Fromentin et al. 1997 for grouping of the southern fjords). The abundance data were transformed (adding a constant of 1 before taking natural logarithms to stabilise the variance; Sen \& Srivastava 1990) and subjected to principal component analysis (PCA; Mardia et al. 1979, Legendre \& Legendre 1983) on the covariance matrix. This procedure downweights the most abundant species somewhat and projects the data onto the main patterns of variation. The resulting ordination of the years according to the 2 main axes of variation was subjected to a non-parametric permutation test of effect of the 1988 algal bloom year and a test for lasting effects of the bloom in the following 3 and 6 yr (Clarke \& Green 1988). The test procedure was applied for the 3 and 6 yr preceding and following 1988. To test whether the observed effects were due to the juveniles stages only, the analyses were repeated, removing the 0-groups of the gadoids (known to exhibit strong stochastic components in their recruitment; Hjort 1914). In the second run, mackerel also was removed due to strong pelagic influence in the catches.

Comparing the structure of the near-shore fish community in 1988 with the 3 and 6 yr before and after, we observed overall a significant difference from Kragerø and westwards, and no difference from Langesund and eastwards (Table 4, Columns 2-4). An exception is the Høvåg area in the western part where no difference was found (Table 4). When the 0-groups of the abundant gadoids were removed from the analysis of the 3 yr before and after the algal bloom, this effect disappeared (Table 4, Column 3). Thus, the strongest impact of the 1988 bloom year was found for the young fish (i.e. gadoid 0-groups).

A comparison of the community during the 3 or $6 \mathrm{yr}$ before the bloom with the corresponding time period after the bloom revealed few significant differences (Table 4, Columns 5-7). Only in the Risør area can a consistent difference over 3 and 6 yr be observed. Less clear differences were observed for the Høvåg/Steindalsfjord, the Sandenesfjord, the Kragerø area and for the Grenland area. For the areas further northeast (from Tjøme) no difference before and after the bloom was observed. Altogether, the near-shore fish communities display weak effects of the 1988 algal bloom.

\section{EFFECTS AT THE COMMUNITY LEVEL: THE BOTTOM BIOTA}

\section{Intertidal and subtidal communities}

Shortly after the Chrysochromulina bloom, a study was initiated to assess the effect on the benthic community in different regions of Skagerrak, and to what extent both the outer coastline and the more sheltered parts among islands and inside fjords were affected. The study focussed on the rocky coast, but effects on intertidal soft bottom fauna were also investigated (Edvardsen et al. 1988). During 6 to 9 June 1988, 17 stations in Langesund, Jomfruland, Risør and Tvedestrand (Fig. 1B) were visited. At Langesund, Jomfruland and Tvedestrand, stations were located along a 
Table 4. Permutation test of principal component analysis (PCA) configurations. Differences significant at the level of $\mathrm{p}<0.1$ are indicated by $+;$ ns: not significant. One outlier of Saithe in the Oslofjord was replaced by the mean. Euclidean distances between all points on the first and second axis of the column scores of the PCA were calculated. Distances were ranked, and the mean rank within groups, $r_{W}$ (i.e. 'not 1988' and 'after 1988') and mean ranks between groups, $r_{B}$ (i.e. '1988-rest', 'before-after') were calculated. Resulting test statistics $R=\left(r_{B}-r_{W}\right) /\{[n(n-1) / 2] / 2\}$ were compared to a frequency distribution of 999 perturbation of the table of ranked distances, and the $\mathrm{H}_{0}$ 'no difference' is rejected at the level of $100(t+1) /(1000+1) \%$ where $t$ is number of values larger than $R$ (e.g. if 25 values of the perturbed table are above $R$, we will get a significance level of [100 $\times 26] / 1001=0.026$ )

(Clarke \& Green 1988)

\begin{tabular}{|c|c|c|c|c|c|c|}
\hline \multirow[t]{2}{*}{ Fjord } & \multicolumn{3}{|c|}{ Difference between 1988 and the rest } & \multicolumn{3}{|c|}{ Difference between post 1988 and pre 1988} \\
\hline & $\begin{array}{c}3 \mathrm{yr} \\
21 \text { species }\end{array}$ & $\begin{array}{l}3 \mathrm{yr} \\
\text { reduced }^{\mathrm{b}}\end{array}$ & $\begin{array}{c}6 \text { yr } \\
21 \text { species }\end{array}$ & $\begin{array}{c}3 \mathrm{yr} \\
21 \text { species }\end{array}$ & $\begin{array}{l}3 \mathrm{yr} \\
\text { reduced }^{\mathrm{a}}\end{array}$ & $\begin{array}{c}6 \mathrm{yr} \\
21 \text { species }\end{array}$ \\
\hline Topdalsfjord & + & ns & + & ns & ns & ns \\
\hline Høvåg/Steindalsfjord & ns & $\mathrm{ns}$ & ns & ns & + & + \\
\hline Flødevigen/Bufjord & + & ns & + & ns & ns & ns \\
\hline Sandenesfjord & + & ns & + & ns & ns & + \\
\hline Risør (Søndeledfjord) & + & ns & + & + & + & + \\
\hline $\begin{array}{l}\text { Kragerø (Stølefjord, Kilsfjord } \\
\text { and Soppekilen) }\end{array}$ & + & ns & + & ns & ns & + \\
\hline Grenland (Langesund in Fig. 1) & ns & ns & ns & + & ns & ns \\
\hline Tjøme & ns & + & ns & ns & ns & ns \\
\hline Holmestrand & ns & ns & ns & ns & ns & ns \\
\hline Inner Oslofjord without outlier & ns & ns & ns & ns & ns & ns \\
\hline Drøbak & ns & ns & ns & ns & ns & ns \\
\hline Hvaler & ns & ns & ns & ns & ns & ns \\
\hline
\end{tabular}

gradient with increasing degree of exposure. In order to study recovery during the first summer (immediately after the 1988 bloom), 9 of these stations were revisited in September/October 1988 (Langesund, 3 sites; Jomfruland, 4; Tvedestrand, 2). Possible long-term effects were investigated at 1 exposed site in each region, and in addition at 2 less exposed sites in the Jomfruland region, all of which were revisited at varying intervals until April 1993.

Only 2 stations (in the Langesund and Jomfruland regions) were sampled for intertidal soft bottom fauna. Ten core samples (diameter $9.5 \mathrm{~cm}$ ) at high and low intertidal level were sieved at $0.5 \mathrm{~mm}$, and animals were identified and counted (Edvardsen et al. 1988). At both stations the samples contained high numbers of the most common representatives of intertidal polychaeta (Nereis diversicolor: 460 to 800 ind. $\mathrm{m}^{-2}$ ), crustacea (Corophium volutator: approx. $280 \mathrm{~m}^{-2}$; Crangon vulgaris: approx. $80 \mathrm{~m}^{-2}$ ), and bivalves (Mya arenaria: 15 to $240 \mathrm{~m}^{-2}$ ). As no apparent effect on this bottom fauna could be detected, these stations were not revisited.

The flora and fauna of hard bottoms were recorded intertidally by surveying segments of the beach (20 to $60 \mathrm{~m}$ dependent on topography). Presence versus absence of common intertidal species were recorded, dead and weakened organisms were also recorded (Edvardsen et al. 1988). The subtidal hard bottom was sampled (with respect to presence-absence) along vertical transects down to $20 \mathrm{~m}$ depth by diving. On most stations the pattern of presence-absence as well as semiquantitative estimates of abundance were recorded during the dive. In addition quantitative data were obtained at a few stations by underwater photography of $50 \times 50 \mathrm{~cm}$ frames from $15 \mathrm{~m}$ depth and upwards. For the study of recovery, quantitative methods (counting of individuals along fixed segments of the shore) and quadrating (either by in situ counting in frames or underwater photography) were used (Gray et al. 1989, Christie et al. 1991, Leinaas et al. 1992, 1994).

During the initial survey, the effects of the bloom on animals were evaluated by the criteria listed in Table 5 . Interpretation of absence (or rarity) of generally common species as indication of increased mortality was based on experience from earlier studies in the Skagerrak area (Lundälv \& Christie 1986, Lundälv et al. 1986) as well as on the species' presence below the affected zone. No sign of mortality was observed in macroalgae, but discoloured fronds were noted as an indication of weakening.

The estimated degree of mortality was grouped into 4 semiquantitative classes (3: total mortality; 2: heavy mortality but some alive within the affected zone; 1: low mortality, most survived; 0: no apparent mortality). For weakened organisms, the degree of weakening was given as: III: more than $75 \%$ of living individuals clearly weakened, II: 25 to $75 \%$ were weakened, 
Table 5. Observed effects of the Chrysochromulina polylepis bloom on common hard bottom invertebrates in localities that were strongly exposed to the toxic algal bloom. These responses are used as criteria for classifying the responses to the bloom

\begin{tabular}{|c|c|c|c|}
\hline & Alive & Dead & Weakened \\
\hline \multicolumn{4}{|l|}{ Intertidal } \\
\hline Littorina littorea & Numerous $^{\mathrm{a}}$ & A few hundred & Large fraction of living snails being inactive ${ }^{b}$ \\
\hline Nucella lapillus & 0 & Thousands & \\
\hline \multicolumn{4}{|l|}{ Subtidal } \\
\hline Asterias rubens & 0 & Hundreds & \\
\hline Sea urchins & 0 & Some ind. & \\
\hline Buccinum undatum & 0 & Some ind. & \\
\hline Monia patelliformes & 0 & Some ind. & \\
\hline Large ascidians $^{c}$ & $0-$ few ind. & Hundreds-thousands & Difficult to evaluate \\
\hline Alcyonium digitatum & Numerous $^{\mathrm{a}}$ & Some ind. & All living inds. hanging down \\
\hline \multirow{2}{*}{\multicolumn{4}{|c|}{$\begin{array}{l}{ }^{\mathrm{b}} \text { The rocky surface between the inactive snails was covered with a distinct film of diatoms showing that they had not been } \\
\text { grazing for some time }\end{array}$}} \\
\hline & & & \\
\hline
\end{tabular}

I: less than $25 \%$ weakened. Tables 6,7 \& 8 summarise the effects on intertidal and subtidal organisms.

The overall pattern of how the various species were affected was similar at all sites; however, sites were affected to different degrees. In the Langesund region only the 3 to $9 \mathrm{~m}$ depth range was affected. In the Jomfruland, Risør and Tvedestrand regions strong effects were seen from the littoral zone down to 9 to $15 \mathrm{~m}$. This corresponds fairly closely with the depth of the thermocline during the first survey. Hence, it seems reasonable to conclude that this layer represented the lower border of the algal distribution during the bloom. Generally the effects were most pronounced at exposed sites. The depth range (and severity) of effects decreased inwards between islands and in the fjords. Similar spatial variations in effects were also observed on the Swedish West Coast (Granmo et al. 1988).

The dog whelk Nucella lapillus was most strongly affected during the algal bloom (Table 6). Also on the
Swedish West Coast the mortality was high; a few survivors were found only on exposed sites (Robertson 1991). All along the Norwegian outer shoreline at Jomfruland, Risør, and Tvedestrand thousands of recently dead individuals (i.e. rotten flesh still present) were found in June, but no living individuals. These observations of dead snails (Edvardsen et al. 1988) indicated pre-bloom densities in the order of $10^{2}$ to $10^{3} \mathrm{~m}^{-1}$ of shoreline. The common shore crab Carcinus maenas was hardly recorded during the first 2 surveys. Dead crabs will disintegrate and be washed away much quicker than the dog whelk. Hence, their striking absence indicates a strong immediate effect. However, since they were recorded in later surveys, the effect of the algal bloom on this species seemed to be of short duration. The common periwinkle Littorina littorea was still abundant after the bloom, but dead shells and low activity in terms of movement indicated a limited immediate effect. No effect was seen on the other lit-
Table 6. Effects of Chrysochromulina polylepis on dominant intertidal fauna in the different regions that survived in June 1988. Semiquantitative estimation of mortality ( 0 to 3 see main text) and degree of weakening in surviving individuals (I-II; see main text). (Species looked for, but not observed are marked with '-'. 0: lack of data, probably no effect)

\begin{tabular}{|c|c|c|c|c|c|c|c|c|}
\hline & \multicolumn{2}{|c|}{$\begin{array}{l}\text { Langesund } \\
\text { Stn } 1 \quad \text { Stn } 4\end{array}$} & \multicolumn{3}{|c|}{$\begin{array}{c}\text { Jomfruland } \\
\text { Stn } 8 \text { Stn } 9 \text { Stn } 12\end{array}$} & $\begin{array}{l}\text { Risør } \\
\text { Stn } 13\end{array}$ & $\begin{array}{l}\text { Tvede } \\
\text { Stn } 14\end{array}$ & $\begin{array}{l}\text { strand } \\
\text { Stn } 15\end{array}$ \\
\hline Littorina saxatilis & & & 0 & & & 0 & 0 & 0 \\
\hline Littorina littorea & 0 & 0 & 2 & $1 / \mathrm{II}$ & 0 & 0 & $1 / \mathrm{I}$ & $1 / \mathrm{I}$ \\
\hline Nucella lapillus ${ }^{\mathrm{a}}$ & - & - & 3 & 3 & 3 & 3 & 3 & 3 \\
\hline Mytilus edulis & 0 & 0 & 0 & 0 & 0 & 0 & 0 & 0 \\
\hline Semibalanus balanoides & 0 & 0 & 0 & 0 & 0 & 0 & 0 & 0 \\
\hline Carcinus maena ${ }^{\mathrm{b}}$ & - & - & - & - & - & - & - & 1 \\
\hline \multicolumn{9}{|c|}{$\begin{array}{l}\text { a Lack of } N \text {. lapillus at Langesund reflects a habitat too sheltered for the species } \\
\text { b Lack of } C \text {. maena at most sites was probably an effect of the algal bloom. Later the } \\
\text { species was found in all areas }\end{array}$} \\
\hline
\end{tabular}

Table 7. Recordings of dog whelks Nucella lapillus at 0 to $2 \mathrm{~m}$ depth along a ca $15 \mathrm{~m}$ horizontal transect at the Jomfruland site

\begin{tabular}{|cc|}
\hline Date & $\begin{array}{c}\text { No. of re- } \\
\text { corded snails }\end{array}$ \\
\hline 8 Sep 1989 & 11 \\
15 Nov 1989 & 15 \\
27 Mar 1990 & 18 \\
19 Jun 1990 & 50 \\
29 Aug 1990 & 439 \\
25 Mar 1991 & 180 \\
3 Jul 1991 & 243 \\
2 Sep 1991 & 207 \\
7 Oct 1992 & 614 \\
22 Apr 1993 & 170 \\
\hline
\end{tabular}


toral periwinkle, Littorina saxatilis, which lives higher up on the beach, and was thus probably not hit by the toxic algae (see below). The barnacle Semibalanus balanoides and the mussel Mytilus edulis as well as various intertidal macroalgae were all exposed to the algal bloom. However, none of them showed any sign of effect in the field. However, Granmo et al. (1988) noted negative effects on fertilisation and early developmental stages of $M$. edulis and the ascidian Ciona intestinalis in experimental vessels, indicating a (possibly delayed) effect on the recruitment of populations exposed to toxic algae.

Except for Nucella lapillus, all the affected intertidal species recovered quickly (by autumn or the next summer; Gray et al. 1989, Christie et al. 1991). Table 7 documents the slow recovery of $N$. lapillus. This may be explained as a result of its limited dispersal ability and reproductive potential. In contrast to almost all the other species of this survey, it produces only relatively few non-pelagic offspring. The recovery may also have been slowing down because of the increasing level of tributyltin (TBT) pollution in the Skagerrak, which is known to cause sterility in N. lapillus (Følsvik et al. 1999). Since the affected population appeared to suffer almost total mortality, the most likely source of recovery was local populations that survived in some deep rock pools. Throughout the time of the algal bloom these pools were isolated from the sea due to high air pressure and low water level.

The bloom affected both sublittoral macroalgae and invertebrates (Table 8). Among the macroalgae, only the red algae (Delesseria sanguinea, Dilsea carnosa and Phycodrys rubens) were affected (Table 7). Their red colour changed to orange and in some cases to green (Edvardsen et al. 1988). By autumn 1988, many plants had reattained their natural colour, notably along their mid ribs, indicating that the weakened plants had recovered over the summer (Gray et al. 1989).

In contrast to the red algae, the subtidal animals had a distribution extending below the affected zone (where healthy specimens were found even in June). The most affected species groups seemed to be echinoderms and ascidians (Table 8). Even though many dead organisms would have disintegrated during the 2 to $3 \mathrm{wk}$ period prior to the survey, many remains of echinoderms were still found. Especially the piles of dead, rotting starfish Asterias rubens demonstrated high mortality of this benthic predator. Sea urchins (Psammechinus miliaris, Strongylocentrotus droebochiensis and Echinus esculentus), as well as the snail whelk Buccinum undatum and the bivalve Monia patelliformis, appeared to have suffered total extermination in the affected zone. Moreover, numerous dead ascidians were still hanging from the rocky substrate (Table 5). Among these, Ciona intestinalis was hardly observed alive above the thermocline at any of the sites, but it was common further below. Ascidiella spp. seemed, on the other hand, slightly less affected (Table 8). The soft coral Alcyonium digitatum was clearly affected. No dead individuals were observed; however, in June all individuals above the thermocline had lost their bright colour and were hanging slack or lying 'weakened' on the bottom (Edvardsen et al. 1988) — in September they had recovered to their normal colour and shape. As most species survived below the affected zone, reproduction could occur along the whole coastline. For the more mobile species, we also observed an upward mi-

Table 8. Effects of Chrysochromulina polylepis on subtidal hard bottom fauna in the different regions that survived in June 1988. Semiquantitative estimation of mortality ( 0 to 3 ; see main text) and degree of weakening in surviving individuals (I-III; see main text). Exposure and deepest recordings of affected fauna are also given. Wave exposure: high (H), medium (M), low (L)

\begin{tabular}{|c|c|c|c|c|c|c|c|c|c|}
\hline & \multicolumn{2}{|c|}{ Langesund } & \multicolumn{3}{|c|}{ Jomfruland } & \multirow{2}{*}{$\begin{array}{r}\text { Risør } \\
\text { Stn } 13\end{array}$} & \multicolumn{3}{|c|}{ Tvedestrand } \\
\hline & Stn 2 & Stn 3 & Stn 8 & Stn 9 & Stn 11 & & Stn 14 & Stn 15 & Stn 16 \\
\hline Delesseria sanguinea & $0 / \mathrm{II}$ & 0/III & 0/III & 0/II & $0 / \mathrm{II}$ & $0 / \mathrm{II}$ & $0 / \mathrm{II}$ & $0 / \mathrm{III}$ & - \\
\hline Phycodrys rubens & & & 0/III & & $0 / \mathrm{II}$ & & & & \\
\hline Dilsea carnosa & 0/II & & 0/III & 0/II & & $0 / \mathrm{II}$ & 0/II & & \\
\hline Alcyonium digitatum & $1 / \mathrm{II}$ & 0 & $1 / \mathrm{III}$ & & & 2/III & $1 /$ III & & $1 / \mathrm{III}$ \\
\hline Buccinum undatum & & & & 3 & 3 & & & & \\
\hline Monia patelliformis & & & & 3 & 3 & 3 & 3 & 3 & \\
\hline Asterias rubens & 2/III & 1 & 3 & 3 & 2 & 3 & 3 & $2 / \mathrm{III}$ & 3 \\
\hline Echinoidea & 3 & & 3 & & 3 & & 3 & 3 & \\
\hline Ciona intestinalis & 2 & & 3 & & 3 & & & & 3 \\
\hline Ascidiella spp. & 2 & 0 & 2 & 2 & 2 & 2 & $2 / \mathrm{III}$ & & 3 \\
\hline Tealia felina & $1 / \mathrm{I}$ & & & 1 & & & 0 & & \\
\hline Metridium senile & & 1 & & & & & & & \\
\hline Wave exposure & $\mathrm{H}$ & $\mathrm{L}$ & M & $\mathrm{H}$ & $\mathrm{L}$ & $\mathrm{H}$ & $\mathrm{H}$ & M & $\mathrm{L}$ \\
\hline Affected to depth (m) & 9 & 9 & 15 & 14 & 15 & 9 & 12 & 11 & 11 \\
\hline
\end{tabular}


gration (Gray et al. 1989). However, even for Asterias rubens the importance of this upward migration was negligible compared to a very successful summer recruitment of larvae later in the same year.

Due to great variation in abundance and spatial distribution of species, it is difficult to determine the duration of the immediate effect caused by the Chrysochromulina bloom. All direct effects in the subtidal seemed, however, to be of limited duration. Most species reinvaded the affected areas within a few months, and seemed to have fully recovered by the following autumn (see Fig. 6).

The algal bloom also caused strong indirect effects in the hard bottom community, mainly initiated by the heavy mortality of the predator Asterias rubens, and probably also the reduced activity of other predators like crabs and fishes. This caused high post-settlement survival of Mytilus edulis with a resulting establishment of an extensive mussel bed, which outcompeted all other sessile organisms (cf. Paine 1966). Fig. 7 illustrates the vertical dominance of this species at the Jomfruland during the years following the bloom. The mussel bed developed during the autumn 1988 and 1989, when a maximum extension down to about $6 \mathrm{~m}$ depth was reached. The starfish Asterias rubens recruited a strong cohort within this mussel bed already in autumn 1988. As these animals grew, they became more efficient predators and by spring 1990 they had eaten most of the continuous subtidal cover of mussels, except for the upper part of the shore where wave action generally is too strong for the starfish (Christie et al. 1991). During 1990-91, the substrate cleared of mussels became dominated by opportunistic annual red algae (notably Ceramium rubrum). Over the next

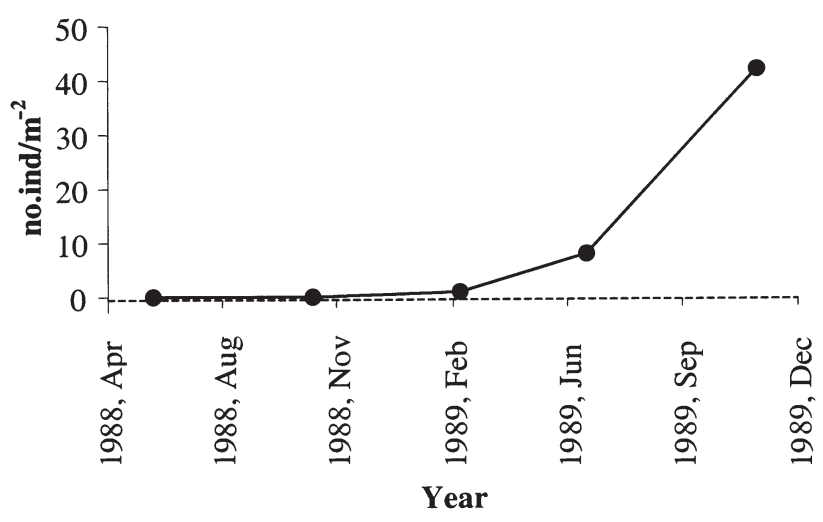

Fig. 6. Recovery of Ascidiacea belonging to the genera Ascidia and Ascidiella at $15 \mathrm{~m}$ depth at Jomfruland after heavy mortality caused by the Chrysochromulina polylepis bloom in 1988. Each estimate is based on analyses of stereo photography of 5 replicate squares of $0.5 \times 0.5 \mathrm{~m}$. At first (spring 1989) recovery was slow, but it increased strongly during summer and autumn the same year

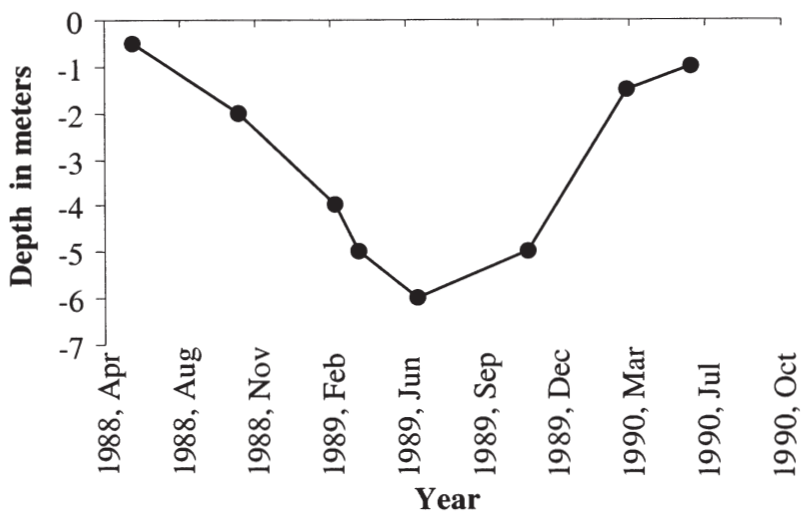

Fig. 7. Change in the vertical distribution of Mytilus edulis at Jomfruland following the Chrysochromulina polylepis bloom. The curve shows the lower limit (cover $>50 \%$ ) of mussel beds extending down from the littoral zone. Analyses are based on 5 replicate squares $(0.5 \times 0.5 \mathrm{~m})$ for each meter depth, except for the upper $2 \mathrm{~m}$, where recordings were done for every $0.5 \mathrm{~m}$

2 yr, however, perennial brown algae Laminaria spp. gradually became dominant in the deeper part of the former mussel bed (from about 3 to $4 \mathrm{~m}$ depth), and thereby re-established a typical benthic community structure for this wave-exposed outer coastline within about 5 yr (Christie \& Rinde 1992, Leinaas et al. 1992, 1994). Thus secondary ecological effects led to significant changes in the benthic community which lasted longer and were even more striking than the direct (fairly short-lasting) effects of the Chrysochromulina polylepis bloom. This was a phenomenon occurring at all the wave-exposed sites of Skagerrak, but not in more sheltered areas. Thus, while the inshore sites recovered from the algal bloom in less than $1 \mathrm{yr}$, effects could be traced for 4 to $5 \mathrm{yr}$ at the outermost sites.

\section{Deep water soft-bottom communities}

For general monitoring purposes subtidal sediment samples had been taken annually since 1986 in parts of the area which experienced high concentrations of toxic algae (Jøssingfjord in Fig. 1B; see Olsgard [1993] for details); these monitoring data may be used for studying the effect of the algal bloom on deep-water soft-bottom communities. Samples were taken at depths ranging from 69 to $184 \mathrm{~m}$ at 10 sites from 1986 to 1991 (i.e. 3 yr before and 3 yr after the algal bloom). A total of 383 species of macrobenthos were identified. Olsgard (1993) found that in the 3 yr prior to the bloom, the fauna at each site exhibited only modest year-toyear changes with respect to the number of species and the abundance of the individual species. Samples collected 1 yr after the bloom revealed a significant 
reduction in numbers of both species and individuals. The most profound changes were observed at sites situated in accumulation areas characterised by fine sediments (indicating a possible relation between the quantity of sinking toxic material and the degree of faunal perturbation; Olsgard 1993). A Detrended Correspondence Analysis (DCA)-ordination of the data demonstrated a clear switch in faunal composition in the study area immediately following the bloom, and a tendency of the fauna to return to the pre-bloom communities 1 to $2 \mathrm{yr}$ after the event. The most heavily affected species included moderately abundant polychaetes, crustaceans, molluscs (mainly bivalves) and sipunculids.

Four of the stations in Olsgard (1993) included all 6 years surveyed. The abundance data (adding a constant of 1 before taking natural logarithms) from the 4 stations surveyed in all 6 years (1986 to 1991) were reanalysed by Principal Component Analysis (PCA) on the covariance matrix (Legendre \& Legendre 1983) to study the effects of the algal bloom. These results were then subjected to the same non-parametric test as used for the fish communities (see e.g. legend to Table 4). Two of the stations showed a lasting effect of the algal bloom (i.e. the years 1989, 1990 and 1991 were closer to each other than to the other years as the years are projected onto the first 2 principal axes of variation in the $\mathrm{PCA}_{;}$Fig. 8), while the other 2 did not show such an effect. The 2 stations displaying a lasting effect (i.e. 3 yr) of the toxic bloom were classified as extreme stations in terms of sediment characteristics in the PCA performed by Olsgard (Fig. 3 in Olsgard 1993). Thus, in these stations (Stns 51 and 59), the biota is adapted to more extreme conditions than for the other stations. Possibly communities at stations that were exposed to stress before the onset of the bloom experienced a slighter effect of the bloom than communities less exposed to stress.

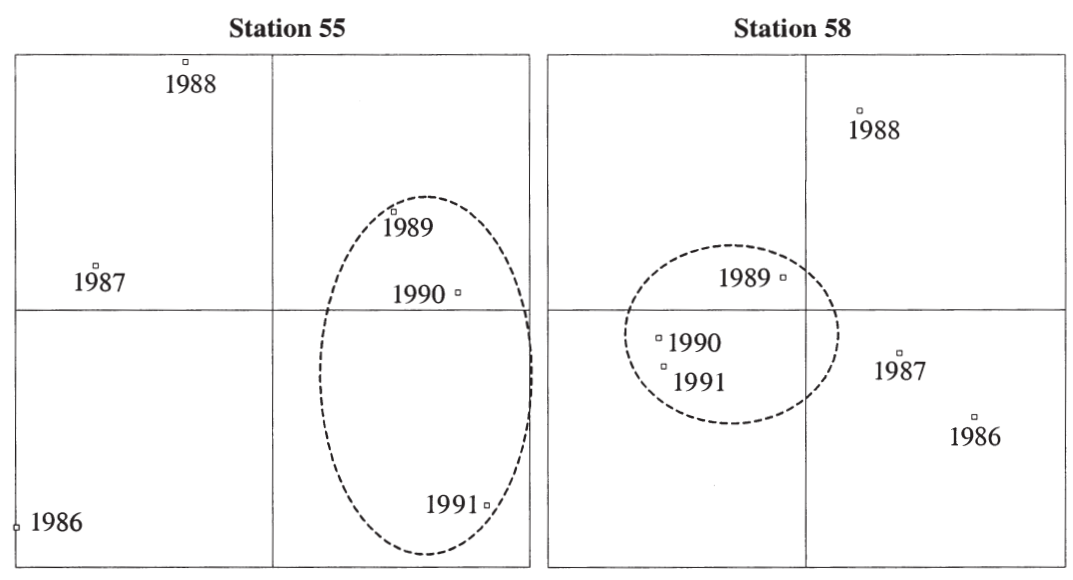

Fig. 8. PCA ordination plot of 1986 to 1991 for Stns 55 and 58 from Olsgard (1993). Significant within grouping of ranked distance is indicated by broken circle

\section{HAS ANYTHING LIKE THIS HAPPENED BEFORE - AND IS IT LIKELY TO HAPPEN AGAIN?}

Chrysochromulina blooms have been reviewed by Edvardsen \& Paasche (1998), revealing that despite world-wide distribution, harmful blooms have so far only been reported from coastal waters in the north Atlantic (i.e. Canada, Denmark, Finland, Norway and Sweden). All these Chrysochromulina blooms have developed in April, May or June, after the regular spring bloom of diatoms. The C. polylepis bloom in May-June 1988 was exceptional in its extent and in its high level of toxicity. On this basis, we may ask if similar blooms are likely to appear in the future. Secondly, if this is the case, are they likely to have similar harmful effects?

In earlier sections of the paper we summarised the environmental conditions which are likely to favour growth of Chrysochromulina polylepis. Strong stratification with a surface layer of high temperature and low salinity was present combined with reduced grazing and increased availability of nutrient (Edvardsen \& Paasche 1998). In summary, this seems to have resulted in the dominance of C. polylepis in the plankton. The normal environmental variability in Scandinavian coastal waters may be such that growth of Chrysochromulina species is favoured at times, leading to modest blooms that generally fail to attract human attention. Several such blooms have indeed occurred (Dahl et al. 1998), however, without any observed harmful effects.

The temperature and run-off in the Skagerrak area are correlated with the North Atlantic Oscillation (NAO; Hurrell 1995, Hurrell \& van Loon 1997; see Fromentin et al. 1998, Post \& Stenseth 1999 for empirical investigations; the NAO being an index measuring the pressure regime in the North Atlantic known to be an effective proxy for the meteorological conditions in the region). Whenever the NAO is in a high phase, we might expect winters with high pressure, high temperature and plentiful precipitation. The different environmental conditions contributing to creating favourable conditions for C. polylepis all occur regularly in the North Atlantic, thus making future blooms of C. polylepis quite likely.

The high level of toxicity of Chrysochromulina polylepis is another issue. After more than a decade of research, the cause(s) of the high toxicity of the 1988 C. polylepis bloom is still not fully understood (Edvardsen \& Paasche 1998). Phosphorus limitation was suggested as 
an explanation shortly after the bloom (Dahl et al. 1989, Edvardsen et al. 1990). Experiments with phosphorus limitation in the laboratory with C. polylepis cells from the 1988 bloom reproduced toxicity, though not as high as the one found in situ (Edvardsen \& Paasche 1998). Thus, phosphorus limitation cannot be the full explanation of the acute toxicity of the bloom. As long as the cause(s) of the toxicity is not fully understood, the C. polylepis bloom in 1988 stands out as an exception. However, taking a precautionary approach, we cannot exclude the possibility that a bloom similar to the one in 1988 might occur again given the right hydrological and environmental conditions (possibly modulated by pollution, e.g. due to run-off of nutrient-rich river water).

Algal blooms like the Chrysochromulina polylepis bloom of 1988 along the Norwegian Skagerrak coast may be considered natural experiments (Myers \& Rothman 1995, Underwood 1996). Interpreting the dynamical effects, both on a shorter and longer time-scale, is important in our efforts to try to understand the dynamic interactions within these communities (Underwood 1989, 1996). However, if such natural experiments are to be interpretable, some sort of referenceor control-is needed. Such a reference can most easily be obtained from long-term monitoring data covering a sufficiently long period before and after the occurrence of the natural experiment (Underwood 1995).

\section{DYNAMICS AND RESILIENCE IN MARINE COMMUNITIES EXPOSED TO EXTERNAL PERTURBATIONS}

The 1988 bloom may properly be seen as an ecological perturbation triggered by peculiar — but not very atypical - hydrographic and meteorological conditions. A theoretical framework emphasising the high level of stochasticity in marine systems (and relating to that, their presumed non-equilibrium nature; cf. Murdoch 1994) may help interpret the apparently short-lasting effects we have observed. The biological responses of marine systems to environmental perturbations may be discussed in terms of their obvious high degree of resilience (i.e. the ability to recover from a high level of stress) and stability (i.e. a fast rate of recovery following a perturbation), although lower degree of inertia (i.e. a weak ability to withstand perturbation; also known as 'resistence' or 'persistence') (see Holling 1973, Pimm 1986, Underwood 1989, 1999). We will discuss these topics with reference to single-species dynamics (i.e. the cod) as well as to larger biotic assemblages (Micheli et al. 1999).
The Chrysochromulina bloom killed many individuals belonging to several different phyla; however, it did not kill uniformly. Crustaceans and some cnidarians were usually less harmed than ascidians, molluscs, sponges, and echinoderms. Evidently, there were great differences in sensitivity towards the algal toxin. Dominant filter-feeders like Mytilus edulis and Semibalanus balanoides were little affected. This could reflect tolerance, but may also be due to little exposure. These littoral species would escape the toxic algae both when not being submerged and possibly by their ability to firmly close their shells. In comparison, the sublittoral bivalve Monia patelliformis suffered very high mortality. Among sensitive animals, the effect on the population level would greatly differ between species restricted to shallow water and those that were also distributed below the thermocline (Nucella lapillus vs Buccinum undatum). The reproductive mode of a species is important for its ability to recover after the initial mortality. High reproductive capacity and widely dispersed larvae, along with survival in deep water, enabled Asterias rubens quickly to return and build up high densities in areas where the algal bloom had caused total mortality. In comparison, $N$. lapillus, with few offspring and direct development, increased very slowly in number. The most striking effects on the benthic community, however, was due to the positive response of Mytilus on the absence of sea stars and other predators the first summer after the algal bloom. This allowed the establishment of a mussel bed that excluded all other sessile organisms far below its normal vertical distribution. The sublittoral mussel bed persisted for about $2 \mathrm{yr}$, but secondary effects on the benthic community could be seen 4 to $5 \mathrm{yr}$ after the algal bloom.

Steele (1985) suggested that marine, as opposed to terrestrial, ecological systems are likely to 'show longer term changes between alternative community structures'. Marine systems are thus expected to be of a non-equilibrium type (Murdoch 1994) and characterised by either switching between 2 or more equilibrium conditions and/or profoundly affected by stochasticity. For a system to be of a non-equilibrium type, non-linearity is required-which is likely to be the case for the particular systems we have considered (see e.g. Bjørnstad et al. 1999b). Equally important is the presence of high level of stochasticity - which is likely to be the case for marine systems (see, e.g. Hjort 1914, Cushing 1990, 1996; see also Stenseth et al. 1999). The coastal ecosystem along the Skagerrak coast is undergoing large natural variations (both within and between years). The temperature shows extensive variation during a year, ranging from a mean temperature of $2.0^{\circ} \mathrm{C}$ in February to $16.8^{\circ} \mathrm{C}$ in August (at $1 \mathrm{~m}$ depth). More often than not, the waters of the Norwe- 
gian Skagerrak coast are covered by ice during shorter or longer parts of the winter, killing and destroying large parts of the sessile animals and plants in the littoral zone. This variation might create a stochasticity, which may induce long-term trends (a non-equilibrium feature) in an otherwise stable system (Bjørnstad et al. 1999a).

The high degree of resilience and stability of the system seems to operate at different levels - both at the demographic level as well as at the population and community level. This implies that at neither of these levels are there any sign of the existence of multiple equilibria (in the sense that some new equilibrium might be attained after the perturbation). Indeed, these systems may properly be said to have a high level of inertia (at various levels).

On the basis of the perturbation event in 1988 and the relative fast recovery (the ecosystem almost completely recovered within 4 to $5 \mathrm{yr}$; see also Southgate et al. 1984), the coastal Norwegian Skagerrak system may further be seen as an example of a system with high stability and resilience (Holling 1973, Underwood 1989, 1999). Even though the 1988 bloom was a particular extensive perturbation, the fast recovery may be an emerging effect of the generally large level of stochastic perturbations in the system (cf. Hjort 1914). Contributing to this high degree of resilience/stability may be the short food chains with many links and compartmentalisation of the community (Pimm \& Lawton 1980). In the sea the barriers to dispersal are weaker due to the continuous nature of the seas and the planktonic dispersal mechanisms of much of the biota (Gee \& Warwick 1996). Combined with the short generation time of most of the organisms in the coastal zone, a quick recovery from perturbations is facilitated (Huston 1979). Hence, even though algal blooms like the one in 1988 may reoccur, such perturbations are unlikely to leave any long-lasting profound effects.

\section{CONCLUSION}

In this review we have summarised available information, all of which suggests that after the severe immediate effects of the Chrysochromulina polylepis algae bloom along the Norwegian Skagerrak coast in 1988 , the ecosystem recovered relatively quickly and completely. On this basis we have discussed whether this was a unique event and concluded that similar algal blooms with comparable ecological effects may occur in the future.

To assess the effects of disturbances on natural systems, a definition of the baseline conditions is necessary (possibly stochastic). For some of the subsystems of the Skagerrak ecosystem long-term monitoring pro- grammes exist and have provided us unique opportunities for our analyses. However, for most ecological subsystems and most groups of species adequate monitoring data do not exist, and thus makes generalisations difficult. It follows that the maintenance of longterm monitoring programmes becomes very important: not only do they put us in a good position to detect deviations early, they may also constitute a platform for interpreting disaster-like situations like the 1988 bloom.

Politicians are generally more eager when initialising investigations and monitoring programmes (as was the case in Norway after the 1988 bloom) than maintaining already running monitoring programmes. This paper has demonstrated the profound value of longterm monitoring programmes, without which we would not have been able to draw many of our conclusions. As climatic variability has increased greatly during the last century we might expect large-scale and extensive disturbances in all ecosystems to also occur in the future. Our ability to handle and, if possible, intervene in these circumstances will be greatly enhanced if society provides the monitoring baseline for understanding ecological disturbance.

Acknowledgements. Thanks are due to institutes maintaining long-term monitoring programmes, especially The Institute of Marine Research maintaining the 'Flødevigen data set' and A/S Miljøplan for monitoring the Jøssingfjord. This paper has benefited from support from the Norwegian Research Council (NFR).

\section{LITERATURE CITED}

Aksnes D, Aure J, Furnes GK, Skjoldal HR, Sætre R (1989) Analysis of the Chrysochromulina polylepis bloom in the Skagerrak, May 1988. Environmental conditions and possible causes. Bergen Scientific Centre, Bergen, p1-38, 28 figs

Aure J, Danielssen D, Svendsen E (1998) The origin of Skagerrak coastal water off Arendal in relation to variation in nutrient concentrations. ICES J Mar Sci 55:610-619

Barth H, Nielsen A (1989) The occurrence of Chrysochromulina polylepis in the Skagerrak and Kattegat in May/June 1988: an analysis of extent, effects and causes. Comm Eur Comm 10:1-96

Bjørnstad ON, Fromentin JM, Stenseth NC, Gjøsæter J (1999a) Cycles and trends in cod populations. Proc Natl Acad Sci 96:5066-5071

Bjørnstad ON, Fromentin JM, Stenseth NC, Gjøsæter J (1999b) A new test for density-dependent survival: the case of coastal cod populations. Ecology 80:1278-1288

Brockmann U, Dahl E (1990) Distribution of organic compounds during a bloom of Chrysochromulina polylepis in the Skagerrak. In: Granéli E, Sundström B, Edler L, Anderson DM (eds) Toxic marine phytoplankton. Elsevier, New York, p 104-109

Burnham KP, Anderson DR (1998) Model selection and inference. A practical information theoretic approach. Springer-Verlag, New York 
Burnham KP, Anderson DR, White GC, Brownie C, Pollock $\mathrm{KH}$ (1987) Design and analysis methods for fish survival experiments based on release-recapture. Am Fish Soc Mon 5:1-437

Christie H, Rinde E (1992) A survey of rocky bottom communities in the coastal aera of Telemark. NINA 133:1-23

Christie H, Leinaas HP, Rinde E, Anstensrud M (1991) Hard bottom communities on the Skagerrak coast after the Chrysochromulina bloom in spring 1988 - results from 1990. NINA 12:1-21

Clarke KR, Green RH (1988) Statistical design and analysis for a 'biological effects' study. Mar Ecol Prog Ser 46: 213-226

Cushing DH (1990) Plankton production and year-class strength in fish populations: an update of the match/mismatch hypothesis. Adv Mar Biol 26:249-293

Cushing DH (1996) Towards a science of recruitment in fish populations. In: Kinne O (ed) Excellence in ecology. Ecology Institute, Oldendorf/Luhe

Dahl E, Johannessen T (1998) Temporal and spatial variability of phytoplankton and chlorophyll $a$ : lessons from the south coast of Norway and the Skagerrak. ICES J Mar Sci 55:680-687

Dahl E, Lindahl O, Paasche E, Throndsen J (1989) The Chrysochromulina polylepis bloom in Scandinavian waters during spring 1988. In: Cosper EM, Bricelj VM, Carpenter EJ (eds) Novel phytoplankton blooms. Springer-Verlag, New York, p 383-405

Dahl E, Edvardsen B, Eikrem W (1998) Chrysochromulina blooms in the Skagerrak after 1988. In: Reguera B, Blanco J, Fernández ML, Wyatt $\mathrm{T}$ (eds) Harmful microalgae. UNESCO, Paris, p 104-105

Danielssen DS, Gjøsæter J (1994) Release of 0-group cod, Gadus morhua L., on the southern coast of Norway in the years 1986-1989. Aquacult Fish Man 25:129-142

Danielssen DS, Svendsen E, Ostrowski M (1996) Long-term hydrographic variation in the Skagerrak based on the section Torungen-Hirtshals. ICES J Mar Sci 53:917-925

Danielssen DS, Edler L, Fonselius S, Hernroth L, Ostrowski M, Svendsen E, Talpsepp L (1997) Oceanographic variability in the Skagerrak and northern Kattegat, May-June, 1990. ICES J Mar Sci 54:753-773

Edvardsen B, Paasche E (1998) Bloom dynamics and physiology of Prymnesium and Chrysochromulina. In: Anderson DM, Cembella AD, Hallegraeff GM (eds) Physiological ecology of harmful algal blooms. Springer-Verlag, Heidelberg, p 193-208

Edvardsen B, Vaulot D (1996) Ploidy analysis of the two motile forms of Chrysochromulina polylepis (Prymnesiophyceae). J Phycol 32:94-102

Edvardsen B, Anstensrud M, Christie H, Fredriksen S, Gray JS, Leinaas HP, Schram T, Saanum I, Winther-Larsen T (1988) Rapport fra undersøkelse om effekter på bunnlevende organismer og strandlevende fisk på kyststrekningen Langesund - Tvedestrand etter oppblomstringen av Chrysochromulina polylepis. University of Oslo, p 1-48 (in Norwegian)

Edvardsen B, Moy F, Paasche E (1990) Hemolytic activity in extracts of Chrysochromulina polylepis grown at different levels of selenite and phosphate. In: Granéli E, Sundström B, Edler L, Anderson DM (eds) Toxic marine phytoplankton. Elsevier, New York, p 284-289

Følsvik N, Berge JA, Brevik EM, Walday M (1999) Quantification of organotin compounds and determination of imposex in populations of dogwhelk (Nucella lapillus) from Norway. Chemosphere 38:681-691

Fromentin JM, Stenseth NC, Gjøsæter J, Bjørnstad ON, Falck
W, Johannessen T (1997) Spatial patterns of the temporal dynamics of three gadoid species along the Norwegian Skagerrak coast. Mar Ecol Prog Ser 155:209-222

Fromentin JM, Stenseth NC, Gjøsæter J, Johannessen T, Planque B (1998) Long-term fluctuations in cod and pollack along the Norwegian Skagerrak coast. Mar Ecol Prog Ser 162:265-278

Gee JM, Warwick RM (1996) A study of global biodiversity patterns in the marine motile fauna of hard substrata. J Mar Biol Assoc UK 76:

Granéli E, Paasche E, Maestrini SY (1993) Three years after the Chrysochroulina polylepis bloom in Scandinavian waters in 1988: some conclusions of recent research monitoring. In: Smayda TJ, Shimizu Y (eds) Toxic phytoplankton blooms in the sea. Proc 5th Int Conf Tox Phytoplankton, Newport, RI, 28 October-1 November, 1991. Elsevier, Amsterdam, p 25-32

Granmo Å, Havenhand J, Magnusson K, Svane I (1988) Effects of the planktonic flagellate Chrysochromulina polylepis Manton et Park on fertilization and early development of the ascidian Ciona intestinalis (L.) and the blue mussel Mytilus edulis L. J Exp Mar Biol Ecol 124:65-71

Gray JS, Anstensrud M, Christie H, Edvardsen B, Leinaas HP (1989) Effekter av oppblomstringen på flora og fauna i kystområdet Langesund - Tvedestrand. I: Oppblomstring av Chrysochromulina polylepis 1988. Oslo, p 35-37

Hjort J (1914) Fluctuations in the great fisheries of northern Europe viewed in the light of biological research. Rapports et procés-verbaux des réunions. Cons Int Explor Mer 20:1-228

Holling CS (1973) Resilience and stability of ecological systems. Annu Rev Ecol Syst 4:1-23

Hurrell JW (1995) Decadal trends in the North Atlantic Oscillation: regional temperatures and precipitation. Science 269:676-679

Hurrell JW, van Loon H (1997) Decadal variations in climate associated with the north Atlantic oscillation. Clim Change 36:301-326

Huston M (1979) A general hypothesis of species diversity. Am Nat 113:81-101

Igarashi T, Oshima Y, Murata M, Yasumoto T (1995) Chemical studies on prymnesins isolated from Prymnesium parvum. In: Lassus P, Arzul G, Erard E, Gentien P, Marcaillou C (eds) Harmful algal blooms. Lavoisier, Paris, p 303-308

Johannessen T, Gjøsæter J (1990) Algeoppblomstringen i Skagerrak i mai 1988 - ettervirkninger på fisk og bunnfauna langs Sørlandskysten. Flødevigen Meldinger 6:1-68 (in Norwegian)

Johnsen TM, Lømsland ER (1990) The culmination of the Chrysochromulina polylepis (Manton and Parke) bloom along the western coast of Norway. In: Granéli E, Sundström B, Edler L, Anderson DM (eds) Toxic marine phytoplankton. Elsevier, New York, p 177-182

Jordan RW, Green JC (1994) A checklist of the extant haptophyta of the world. J Mar Biol Assoc UK 74:149-174

Julliard R, Stenseth NC, Gjøsæter J, Lekve K, Fromentin JM, Danielssen DS (2000) Natural and fishing morality in a cod population along the Norwegian Skagerrak coast: a release-recapture experiment. Ecol Appl (in press)

Kawachi M, Inouye I (1995) Functional roles of haptonema and the spine scales in the feeding process of Chrysochromulina spinifera (Fournier) Pienaar et Norris (Haptophyta = Prymensiophyta). Phycologia 34:193-200

Lebreton JD, Burnham KP, Clobert J, Anderson DR (1992) Modelling survival and testing biological hypotheses using marked animals: a unified approach with case studies. Ecol Monogr 62:67-118 
Legendre L, Legendre P (1983) Numerical ecology. Elsevier, Amsterdam

Leinaas HP, Christie H, Rinde E (1992) The development of hard bottom communities on the Skagerrak coast after the Chrysochromulina bloom in spring 1988 - results from 1991. NINA 160:1-22

Leinaas HP, Christie H, Rinde E (1994) The development of hard bottom communities on the Skagerrak coast after the Chrysochromulina bloom in spring 1988 - results from 1992-93. NINA 264:1-16

Leivestad H, Serigstad B (1988) Some observations on the effects of Chrysochromulina polylepis on the osmoregulation in fish. Inst Mar Res 3:1-12

Lekve K, Stenseth NC, Gjøsæeter J, Fromentin JM, Gray JS (1999) Spatio-temporal patterns in diversity of a fish assemblage along the Norwegian Skagerrak coast. Mar Ecol Prog Ser 178:17-27

Lindahl O, Dahl E (1990) On the development of the Chrysochromulina polylepis bloom in the Skagerrak in May-June 1988. In: Granéli E, Sundström B, Edler L, Anderson DM (eds) Toxic marine phytoplankton. Elsevier, New York, p 189-194

Lundälv T, Christie H (1986) Comparative trends and ecological patterns of rocky subtidal communities in the Swedish and Norwegian Skagerrak area. Hydrobiologia 142:71-80

Lundälv T, Larsson C, Axelsson L (1986) Long-term trends in algal-dominated rocky subtidal communities on the Swedish west coast - a transitional system? Hydrobiologia 142:81-95

Mardia KV, Kent JT, Bibby JM (1979) Multivariate analysis. Academic Press, London

Micheli F, Cottingham KL, Bascompte J, Bjørnstad ON, Eckert GL, Fisher JM, Keitt TH, Kendall BE, Klug JL, Rusak JA (1999) The dual nature of community variability. Oikos 85:161-169

Murdoch WW (1994) Population regulation in theory and practice. Ecology 75:271-287

Myers JH, Rothman LD (1995) Field experiments to study regulation of fluctuating populations. In: Cappuccino N, Price P (eds) Population dynamics. Academic Press, New York, p 229-251

Olsgard F (1993) Do toxic algal blooms affect subtidal softbottom communities? Mar Ecol Prog Ser 102:269-286

Paine RT (1966) Food web complexity and species diversity. Am Nat 100:65-75

Pimm SL (1986) Comunity stability and structure. In: Soulé ME (ed) Conservation biology. Sinauer Assiciates Inc., Sunderland, MA, p 309-329

Pimm SL, Lawton JH (1980) Are food webs divided into compartments? J Anim Ecol 49:879-898

Editorial responsibility: Otto Kinne (Editor),

Oldendorf/Luhe, Germany
Post E, Stenseth NC (1999) Climatic variability, plant phenology and northern ungulates. Ecology 80:1322-1339

Robertson A (1991) Effects of a toxic bloom of Chrysochromulina polylepis on the common dog-whelk, Nucella lapillus, on the Swedish west coast. J Mar Biol Assoc UK 71: $569-578$

Sen A, Srivastava M (1990) Regression analysis: theory, methods, and applications. Springer-Verlag, New York

Skjoldal HR, Dundas I (1991) The Chrysochromulina polylepis bloom in the Skagerrak and the Kattegat in May-June 1988: environmental conditions, possible causes, and effects. ICES Coop Res Rep 175:1-59

Sokal RR, Rohlf FJ (1995) Biometry. The principles and practice of statistics in biological research. WH Freeman \& Co, New York

Southgate T, Wilson K, Cross TF, Myers AA (1984) Recolonization of a rocky shore in S.W. Ireland following a toxic bloom of the dinoflagellate, Gyrodinium aureolum. J Mar Biol Assoc UK 64:485-492

Steele JH (1985) Comparison of marine and terrestrial ecological systems. Nature 313:355-358

Stenseth NC, Bjørnstad ON, Falck W, Fromentin JM, Gjøsæter J, Gray JS (1999) Dynamics of coastal cod populations: intra- and intercohort density dependence and stochastic processes. Proc R Soc Lond B 266:1645-1654

Tveite S (1971) Fluctuations in year-class strength of cod and pollack in southeastern Norwegian coastal waters during 1920-1969. Fiskeridir Skr Ser Havunders 16:65-76

Underdal B, Skulberg OM, Dahl E, Aune T (1989) Disastrous bloom of Chrysochroulina polylepis (Prymnesiophyceae) in Norwegian coastal waters 1988 - mortality in marine biota. Ambio 18:265-270

Underwood AJ (1989) The analysis of stress in natural populations. Biol J Linn Soc 37:51-78

Underwood AJ (1995) Ecological research and (and research into) environmental management. Ecol Appl 5:232-247

Underwood AJ (1996) Detection, interpretation, prediction and management of environmental disturbances: some roles for experimental marine ecology. J Exp Mar Biol Ecol 200:1-27

Underwood AJ (1999) Physical disturbances and their direct effect on an indirect effect: reponses of an intertidal assemblage to a severe storm. J Exp Mar Biol Ecol 232: $125-140$

Yasumoto T, Underdal B, Aune T, Hormazabal V, Skulberg O, Oshima Y (1990) Screening for hemolytic and ichthyotoxic components of Chrysochromulina polylepis and Gyrodinium aureolum from Norwegian coastal waters. In: Granéli E, Sundström B, Edler L, Anderson DM (eds) Toxic marine phytoplankton. Elsevier, New York, p 436-440

Submitted: May 9, 2000; Accepted: September 14, 2000 Proofs received from author(s): October 25, 2000 